\title{
Exploring Causes of Delays in National Road and Highway Projects in Developing Construction Economy
}

\author{
Sebghatullah Karimi ${ }^{1}$ and Poorang Piroozfar ${ }^{2}$ \\ ${ }^{1}$ Senior Lecturer, Civil Engineering, Faculty of Construction, Kabul Polytechnic University, Kabul, Afghanistan. E-mail: \\ s.karimi@kpu.edu.af \\ ${ }^{2}$ Reader, Architectural Technology and Digital Construction, Digital Construction Lab, School of Architecture, Technology and \\ Engineering, University of Brighton, Brighton, UK. E-mail: aep15@brighton.ac.uk (corresponding author).
}

Project Management

Received May 12, 2021; revised December 3, 2021; December 26, 2021; accepted December 28, 2021

Available online February 12, 2022

\begin{abstract}
Delay in construction projects, especially in road and highway projects, is a universal phenomenon. Afghanistan construction industry is no exception. There are factors causing delays in the Afghanistan construction industry which have negative effects on the key project stakeholders and the project's deliverables and outcomes. This research aims to identify the causes of delays that affect highway and road projects in Afghanistan and to provide recommendations in order to minimize or control delays in such projects. This will help, in return, facilitate and improve the delivery of roads and highways projects in Afghanistan. To achieve this aim, the study sets out to achieve the following objectives: 1) to determine the most important causes of delay that affect road and highway projects in Afghanistan, 2) to identify the severity of the delay causes from clients' and contractors' perspectives, 3 ) to investigate the differences and discrepancies between clients' and contractors' opinions and views, and based on first three objectives, 4) to finally provide recommendations for minimizing and/or controlling delays in road and highway projects, to improve the status-quo and to facilitate procurement/delivery of road and highway projects in Afghanistan. Causes of delay were gathered upon conducting a critical literature review of different types of construction, in different countries. An expert interview and a questionnaire survey formed the basis of this paper, listing 29 important causes of delay in such projects. The major causes of delay then were categorized into three groups following main stages of the highway projects, namely: 1) preparation, 2) procurement, and 3) implementation. The questionnaire survey was distributed to 100 construction participants and 79 were received who represent the government in road projects and contractors. Relative importance index (RII) was calculated and according to the highest values the top ten delay causes of road projects in Afghanistan were determined. Spearman correlation index was used to assess the correlation of causes and groups between clients and contractors. The findings of the study revealed that the top 10 significant factors causing a delay in road projects in Afghanistan are; security (war, theft, kidnapping, etc.), shortage of equipment and material or financial status of contractors, land acquisition, corruption in the procurement process, progress payment delays by owners/clients, non-consideration of security risks in the procurement process, Inaccurate design and bills of quantities, insufficient contractors' experience, poor qualification of the contractors' technical staff and award project to lowest bids. The findings will help clients and contractors to mitigate or prevent delays in road and highway projects in Afghanistan. Finally, to help overcome delays in road and highway projects more effectively, recommendations have been made for fundamental reforms in procurement systems for major projects.
\end{abstract}

Keywords: Road projects, highway projects, causes of delay, construction industry, developing countries, Afghanistan.

Copyright $\odot$ Journal of Engineering, Project, and Production Management (EPPM-Journal).

DOI 10.32738/JEPPM-2022-0013

\section{Introduction}

Afghanistan is a landlocked country. To improve regional and international trade and provide access to markets across the country, construction of roads and highways on time and within budget is key and therefore, one of the Afghanistan Government's top priorities. For a country suffering from endemic levels of unemployment, the ability to connect people, goods and services provide a critical opportunity for social and economic development as it rebuilds after nearly three decades of war. However, the 2016-2017 Afghanistan living conditions survey revealed that just $63 \%$ of the rural population lives within $2 \mathrm{~km}$ of an "all-season road" (one which is motorable all year). Based on the survey, the road density as of 2011 is estimated at a low $3.5 \mathrm{~km}$ per $100 \mathrm{~km}^{2}$ of territory, which is below the road density in Afghanistan's neighbouring countries (For instance, according to Knoema (2020), the road density for 
Afghanistan's neighbouring countries are: $13.1 \mathrm{~km}$ per 100 $\mathrm{km}^{2}$ for Iran (2011), $33 \mathrm{~km}$ per $100 \mathrm{~km} 2$ for Pakistan(2011), $19.5 \mathrm{~km}$ per $100 \mathrm{~km}^{2}$ for Tajikistan (2000), $18.2 \mathrm{~km}$ per 100 $\mathrm{km}^{2}$ for Uzbekistan (2000) and $4.9 \mathrm{~km}$ per $100 \mathrm{~km} 2$ for Turkmenistan (2000)).

Afghanistan's Ministry of Public Works (MoPW) (formerly, Ministry of Transport (MoT)) is responsible for the development, and operation and maintenance (O\&M) of the strategic road network (SRN). According to MoT's

2019-2023 Strategy which is developed based on Afghanistan Transport Sector Master Plan (2017-2036), the road network, which includes national highways, provincial and district roads, has a total estimated length of $21,752 \mathrm{~km}$ (Table 1). The national highways, including the international connections, cover a length of about $6,472 \mathrm{~km}$, of which $3,720 \mathrm{~km}$ is tarmacked. The remaining, $2,752 \mathrm{~km}$ is in different stages of construction and planning. Based on estimates by Baligh (2017), around USD 25.9 billion is needed to finance Afghanistan's Transport Sector Master Plan (2017-2036), which exceeds available resources from development partners and domestic fiscal resources. According to MoT's 2019-2023 Strategy, around 43\% of the national highways are under planning and construction. This illustrates the challenges associated with connectivity in road and highway networks, and its recurring impacts on the economy and social welfare.

Over the past decade, the government has prioritized the construction and maintenance of road and highway networks in the country with the direct technical and financial support of the international community such as USAID and the provincial reconstruction team (PRT). According to the Ministry of Finance, between 2004 and 2018 some USD 33 billion has been invested in rehabilitation and reconstruction of the country as a part of the national development budget . In addition, multilateral organizations such as the World Bank, and Asian Development Bank are investing tremendously in Afghanistan's roads and highways network through the Afghanistan Reconstruction Trust Fund (ARTF) and the Afghanistan Infrastructure Trust Fund (AITF). Between 2002 and 2016, only USAID and DOD spent approximately USD 2.8 billion to construct and repair Afghanistan's road infrastructure and to carry out capacity-building activities (SIGAR, 2016). However, the effectiveness and efficiency of such huge expenditures have been challenged by the lack of technical capacity, especially, in project preparation and implementation stages coupled with the lack of transparency and accountability in the project delivery system.

Construction of roads on time and within budget requires proper planning and budgeting to ensure the project success. One of the main challenges the Afghanistan government is faced with is the on-time completion of road projects. According to the construction sector transparency's (CoST) first assurance report (2018), the construction projects in Afghanistan are facing an average of $119 \%$ time-overruns. In some road projects, the delay exceeds the total initial duration of the original contract with cases where the project has been delayed by up to $200 \%$ of the initial contract period (CoST 2018. p.28). Another study by CoST in 2019 also identified delay as the most important factor influencing the implementation of infrastructure projects, especially, highway projects. There are road projects in the heart of the capital which has suffered from delays three times the original contract duration (CoST 2019).

To alleviate the impact of delays on highway projects, the government and contractors need to identify the key causes of delays and recognize important areas in the project delivery system for improvements. Most of the recent research conducted in Afghanistan, did not clearly study factors with a focus on different stakeholder groups, and even less so especially, in highway projects. Moreover, the causes of delays are not merely restricted to implementation stages of a project; there are also some major problems associated with the projects both at preparation and procurement stages.

This research aims to determine the causes of delays that affect road and highway projects in Afghanistan and to provide recommendations to help reduce or manage delays in such projects. This will help, in return, facilitate and improve the delivery of roads and highways projects in Afghanistan. To achieve this aim, the study sets out to achieve the following objectives: 1) to identify the most important causes of delay that affect road and highway projects in Afghanistan, 2) to identify the severity of the delay causes from clients' and contractors' perspectives, 3 ) to investigate the differences and discrepancies between clients' and contractors' opinions and views, and based on first three objectives, 4) to finally provide recommendations to help minimize or control delays in road and highway projects, to improve the status-quo and to facilitate procurement/delivery of road and highway projects in Afghanistan.

\section{Previous Works and Related Studies}

Delay in construction projects, especially on highways, is a universal phenomenon, causing a multitude of negative impacts on the key project stakeholders - clients, contractors and the general public. There are different definitions of delay in the corresponding literature. Delay is defined as the time overrun either beyond the completion date as specified in a contract, or beyond the date that the parties agreed upon for delivery of a project (Assaf and AlHejji, 2006). To the owner, a delay means loss of revenue through tax dependency of the present project. In some cases, to the contractor, a delay means higher overhead costs because of the longer work period, higher material costs due to inflation, and labor costs increase (Assaf and Al-Hejji, 2006).

Table 1. Strategic road network (adopted from MoT's 2019-2023 Strategy)

\begin{tabular}{cccccccc}
\hline \multirow{2}{*}{ Road Class } & \multicolumn{3}{c}{ Existing length $(\mathbf{k m})$} & \multicolumn{3}{c}{ Ongoing/pipeline/planned (km) } & Total (km) \\
\cline { 2 - 7 } & Asphalt & DBST $^{\mathbf{1}}$ & Gravel & Ongoing & Pipeline & planned & \\
\hline National Highways & 3,720 & & 33 & 1,099 & 722 & 902 & 6,476 \\
Provincial Roads & 732 & 383 & 24 & 396 & & 397 & 1,932 \\
District Roads & 2,743 & & 10,469 & 15 & & 117 & 13,344 \\
Total $(\mathrm{km})$ & 7,195 & 383 & 10,526 & 1,510 & 722 & 1,416 & 21,752 \\
\hline
\end{tabular}

${ }^{1}$ Double Bituminous Surface Treatment 
According to Ahmed et al. (2001), a delay is the most common, costly, and risky problem in construction projects. Delays could lead to time overruns and cost overruns in affected projects (Dissanayaka and Kumaraswamy, 1999; Frimponga et al., 2003; Sambasivan and Soon, 2007). Yet, some delays are excusable and eligible for time extensions and/or cost claims (Palaneeswaran and Kumaraswamy, 2008). Nonetheless, most delays affect the reputation of contractors and subcontractors (Orangi et al., 2011). Therefore, completing construction projects on time and on a budget should ideally follow the $3 \mathrm{E}$ indicator (efficiency, economy, and effectiveness). In reality, completing a project on time and within the budget is not an easy task. Construction projects are subject to many variables and unpredictable incidents. These issues causing or affecting delays range from material availability to weather conditions, and from clients' and/or contractors' performances to contractual relations and legal technicalities and processes.

From a liabilities point of view, delays have been categorized into two major types namely excusable and inexcusable delays (Menesi, 2007). Excusable delays are further classified into compensable and non-compensable delays (Menesi, 2007). Delays may be caused by the contractor (non-excusable delay), a third party or the owner or considered as an "act of God" (excusable delay which may or may not be compensable due to the context and conditions). In real life, several delays of the same or different types may and normally do happen concurrently (Aziz and Abdel-Hakam, 2016).

Several studies have been conducted around the world to identify the causes and effects of delays. There are numerous factors contributing to delays and the sensitivity and importance of these factors vary from one country to another and even from one project to the other. The critical review of the literature on delays revealed that the number and types of causes of delay and methods of ranking them are vastly different in each study. Causes of delay varied from 7 in Hong Kong to 113 in Malaysia (Aziz and Abdel-Hakam, 2016), mostly due to substantial systemic differences between methods of classification adopted.

Research on hospital projects in Vietnam identified 33 delay-related factors and ranked their importance (Kim et al., 2016). The study revealed that the top five reasons for the delay in hospital projects in Vietnam were: 1) financial difficulties on the owner/client side, 2) problems associated with supervisor's responsibility, 3) owner/client design change, 4) incompetent contractors, and 5) insufficient contractor experience (factors 4 and 5 are practically the same but separated by the researchers with no further explanation or justification provided). Alaghbari et al. (2007) believe that the most significant factors causing delays in Malaysian building and construction projects are financial problems and lack of cooperation between stakeholders.

A study of the causes of delays in building construction projects in Egypt indicated the most significant causes of delay as 1) financing by the contractor during construction, 2) partial payments during construction and, 3) nonutilization of professional contractual management (Abd ElRazek et al., 2008). Another study on the causes and effects of construction delays on completion cost of housing projects in Nigeria categorized the causes of delay under project participants and extraneous factors (Odeyinka and Yusif, 1997). In delays caused by project participants, slow decision-making processes and cash flow problems were highlighted as client-related delays, whereas contractorrelated delays were financial difficulties, poor planning and scheduling, mismanagement of material, equipment [and processes], inadequate or ineffective site inspection, and shortage of [skilled] workforces. The extraneous causes of delay were identified as extreme weather conditions, and acts of nature (e.g., flood, storm, earthquake, etc.), labour disputes and strikes.

A study on road construction projects In Palestine indicated 52 causes for delays (Mahamid et al., 2012). The top five factors were 1) political complications, 2) restricted movement between the area of West Bank segmentations (in Palestine, the geographical location of this research), 3) awarding the project to lowest bids, 4) progress payment delay by owner/client and 5) equipment shortage which had impacts on project progress and performance. A report by Thailand's Department of Highways asserted that there were eight important factors causing delays in highway projects: 1) piecemeal drawings, 2) equipment inefficiency (or fitness for the purpose) or financial status of contractors, 3) delay in repositioning old infrastructure, 4) lack of project engineer's experience, 5) delay in approving environmental impact documents, 6) lack of traffic safety during construction, 7) lack of management training for monitoring construction operations, and 8) material shortage.

Common causes of delays in the construction industry (including but not exclusive to road and highway projects) in Afghanistan were studied by Gidado and Niazi (2012), whose findings indicated the main critical factors in this regard are: 1) security, 2) corruption, 3) poor (or lack of) qualification in contractor's technical team, 4) delays in payment by clients, and 5) contractor's poor practice in site supervision and/or management. They went on to provide some recommendations to reduce the impact of delays on construction projects in Afghanistan.

A study by Construction Sector Transparency Initiative in 2018 on eight infrastructure projects, underlined the major causes of delay as 1) inaccurate design and bills of quantities, 2) inflation (exchange rate/escalation) and, 3) local communities demand for change. In another study, which assessed 20 construction projects, highlighted these factors as the major causes of delay: 1) land acquisition, 2) inaccurate survey, 3) poor design and errors in bills of quantities (BoQ), 4) weather, and 5) difficulties in financing project by contractors (CoST 2nd assurance report, 2019). However, in this report the importance of these factors is not ranked. In addition, the causes of delays in these reports do mostly cover all types of construction projects and are not exclusive to roads and highways projects.

As shown in the aforementioned literature, the majority of the research projects in Afghanistan and around the world focus on identifying causes of delay in general construction projects and there are few types of research to study the causes of delay in the road and/or highway projects in some developing countries and none in Afghanistan. To highlight this very pressing and substantial gap in knowledge, the current study investigates causes of delays in road and highway projects which both contribute to our understanding of this area specific to the construction industry in Afghanistan, and feeds back into the decision- and policymakers in public bodies, local authorities and central government to help them tackle some of the problems associated with such projects as a matter of national priority. In doing so, the first step would be identifying the root causes 
and recognizing the fundamental principles of road and highway construction projects.

\section{Research Design and Methodology}

The research was initiated with an in-depth critical literature review to help provide a comprehensive understanding of the causes of delays in highway projects in Afghanistan. This was then used as the underlying foundation for the design of this research and subsequently for the design of its research instrument. Afghanistan's political and economic environments, where potential impacts on the delivery of road and highway projects could be tracked, were investigated. Research/studies carried out on construction delays in Palestine, Thailand, Vietnam, Malaysia and some other developing countries were deployed to help this study to effectively learn from the closest and most relevant precedents. In addition, road case studies in Afghanistan have been reviewed to find out about the causes of delay, to assist in developing the research instruments (interview and questionnaire survey).

The literature review was also utilized to reflect on the common research design, methodology and methods used by similar precedent research. Related literature on construction, road and highway project delays indicated that both qualitative and quantitative research approaches had been used to identify causes of delays in such projects. Table 2 summarizes the research design developed for or adopted in different developing construction economies. It shows some common patterns with a few minor differences. For instance, in Egypt, desk study, personal interviews and questionnaire surveys were used while in some other countries only desk-based research and questionnaire surveys were adopted. This is determined by different factors such as the level and depth of existing knowledge of the scope in the context of the study, the aim and/or objectives of the research, the resources available and the intended outcomes or deliverables of the study, to name but a few. Another important issue that was noticed during the review of research methodologies was the sampling strategy. Researchers mostly used a random sampling strategy ranging from 60 participants in Afghanistan to 500 participants in Egypt for quantitative approaches. There is no agreed sample size among researchers, which can be explained due to the availability or willingness of participants and the research scope. A questionnaire survey with a five-point Likert scale was used widely. Furthermore, it was also noticed that almost all researchers used the relative importance index (RII) and Spearman's rank correlation coefficient as the main tool for analyzing data.

Table 2. Research design utilized in previous studies on construction, road and highway delays

\begin{tabular}{|c|c|c|c|c|c|c|}
\hline Source & $\begin{array}{l}\text { Context/ } \\
\text { country }\end{array}$ & $\begin{array}{c}\text { Research } \\
\text { methodology }\end{array}$ & $\begin{array}{c}\text { Research } \\
\text { method }\end{array}$ & Sampling (size, strategy, etc.) & Data collection strategy & Source \\
\hline $\begin{array}{l}\text { Aziz and } \\
\text { Abdel- } \\
\text { Hakam } \\
\text { (2016) }\end{array}$ & Egypt & $\begin{array}{l}\text { Qualitative } \\
\text { and } \\
\text { quantitative }\end{array}$ & $\begin{array}{l}\text { Desk-based } \\
\text { research, } \\
\text { personal } \\
\text { interview, and } \\
\text { questionnaire }\end{array}$ & $\begin{array}{l}\text { A questionnaire was sent to } 500 \\
\text { construction participants, including } \\
\text { consultants, contractors, and } \\
\text { site/design engineers. } 389 \\
\text { questionnaires were received. }\end{array}$ & $\begin{array}{l}\text { Questionnaire survey with a } \\
\text { five-point Likert scale }\end{array}$ & $\begin{array}{l}\text { RII and } \\
\text { Spearman's rank } \\
\text { correlation } \\
\text { coefficient }\end{array}$ \\
\hline $\begin{array}{l}\text { Alaghbari } \\
\text { et al. } \\
\text { (2007) }\end{array}$ & $\begin{array}{l}\text { Malays } \\
\text { ia }\end{array}$ & $\begin{array}{l}\text { Qualitative } \\
\text { and } \\
\text { quantitative }\end{array}$ & $\begin{array}{l}\text { Desk-based } \\
\text { research and } \\
\text { questionnaire }\end{array}$ & $\begin{array}{l}\text { The sample was selected randomly } \\
\text { and focused on construction } \\
\text { projects. The respondents were } \\
\text { contractors, consultants, developers, } \\
\text { subcontractors, engineers, and } \\
\text { architects. The } 78 \text { out of } 450 \\
\text { responses were collected for the } \\
\text { questionnaire survey. }\end{array}$ & $\begin{array}{l}\text { Questionnaire survey with } \\
\text { the four-point Likert scale }\end{array}$ & $\begin{array}{l}\text { Mean score } \\
\quad(\mathrm{MS})\end{array}$ \\
\hline $\begin{array}{l}\text { Frimponga } \\
\text { et al. } \\
\text { (2003) }\end{array}$ & Ghana & $\begin{array}{l}\text { Qualitative } \\
\text { and } \\
\text { quantitative }\end{array}$ & $\begin{array}{l}\text { Desk-based } \\
\text { research and } \\
\text { questionnaire }\end{array}$ & $\begin{array}{l}\text { A questionnaire was sent to } 125 \\
\text { participants, including owners, } \\
\text { contractors, and consultants. The } 72 \\
\text { questionnaires were returned } \\
\text { completed }\end{array}$ & $\begin{array}{l}\text { Questionnaire survey with a } \\
\text { five-point Likert scale }\end{array}$ & $\begin{array}{l}\text { Relative } \\
\text { Importance weight } \\
\& \text { Kendall's } \\
\text { coefficient of } \\
\text { concordance } \\
\end{array}$ \\
\hline $\begin{array}{l}\text { Gidado } \\
\text { and } \\
\text { Niazai } \\
(2012)\end{array}$ & $\begin{array}{l}\text { Afghanist } \\
\text { an }\end{array}$ & $\begin{array}{l}\text { Qualitative } \\
\text { and } \\
\text { quantitative }\end{array}$ & $\begin{array}{l}\text { Desk-based } \\
\text { research and } \\
\text { questionnaire }\end{array}$ & $\begin{array}{l}\text { The sample was selected } \\
\text { randomly. The } 60 \text { construction } \\
\text { company stakeholders including } \\
20 \text { clients, } 25 \text { contractors, and } 15 \\
\text { consultants. }\end{array}$ & $\begin{array}{l}\text { Questionnaire survey with a } \\
\text { five-point Likert scale }\end{array}$ & $\begin{array}{l}\text { Importance index } \\
\text { and Spearman's } \\
\text { rank correlation } \\
\text { coefficient }\end{array}$ \\
\hline $\begin{array}{l}\text { Mahamid. } \\
\text { et al. } \\
\text { (2012) }\end{array}$ & Palestine & $\begin{array}{l}\text { Qualitative } \\
\text { and } \\
\text { quantitative }\end{array}$ & $\begin{array}{l}\text { Desk-based } \\
\text { research and } \\
\text { questionnaire }\end{array}$ & $\begin{array}{c}\text { The sample was selected randomly. } \\
\text { The survey targeted contractors and } \\
\text { consultants not clients. } 64 \text { out of } 80 \\
\text { questionnaires were received. }\end{array}$ & $\begin{array}{l}\text { Questionnaire survey with a } \\
\text { five-point Likert }\end{array}$ & $\begin{array}{c}\text { Severity index } \\
\text { and Spearman } \rho\end{array}$ \\
\hline $\begin{array}{l}\text { Long et } \\
\text { al. (2008) }\end{array}$ & Vietnam & $\begin{array}{l}\text { Qualitative } \\
\text { and } \\
\text { quantitative }\end{array}$ & $\begin{array}{l}\text { Desk-based } \\
\text { research and } \\
\text { questionnaire }\end{array}$ & $\begin{array}{c}\text { The survey targeted the owner, } \\
\text { consultant, and contractor. } 87 \text { out } \\
\text { of } 285 \text { questionnaires were } \\
\text { returned. }\end{array}$ & $\begin{array}{l}\text { Questionnaire survey with a five- } \\
\text { point Likert scale }\end{array}$ & $\begin{array}{l}\text { Frequency, } \\
\text { severity and } \\
\text { importance indices } \\
\text { and Spearman's } \\
\text { rank correlation }\end{array}$ \\
\hline $\begin{array}{l}\text { Odeyinka } \\
\text { and Yusif } \\
(1997)\end{array}$ & Nigeria & $\begin{array}{l}\text { Qualitative } \\
\text { and } \\
\text { Quantitative }\end{array}$ & $\begin{array}{l}\text { Desk-based } \\
\text { research and } \\
\text { questionnaire }\end{array}$ & $\begin{array}{l}\text { A stratified random sampling } \\
\text { strategy is applied. The survey } \\
\text { targeted the owner, consultant, } \\
\text { and contractor. }\end{array}$ & $\begin{array}{l}\text { Data were collected through two } \\
\text { sets of questionnaires to 1) identify } \\
\text { causes of construction delay and, 2) } \\
\text { collect details of housing projects in } \\
\text { terms of construction costs and } \\
\text { delays }\end{array}$ & $\begin{array}{l}\text { Importance } \\
\text { index and } \\
\text { regression } \\
\text { analysis }\end{array}$ \\
\hline
\end{tabular}


To select a reliable number of informants for interviews, the review of research literature suggested some guidelines which were adopted and applied in this study. Creswell (2002) recommends that 3-5 participants be used for case study research, along with other types of data. With respect to phenomenological studies - similar to the approach of the current study - sample size recommendations range from 6 (Morse and Chung, 2003) to 10. Therefore, to finalize and contextualize the delay causes in the Afghanistan construction context, a semi-structured interview was designed and 6 interviews were arranged and conducted to have construction professionals' expert opinions about the causes of delays in highways projects' preparation, procurement, and implementation in Afghanistan. Interviewees consisted of construction managers, procurement managers and road project chief/lead designers. Based on the result of the interviews, some new causes were added to the list, merged with others, split into more detailed or specific items, or otherwise altered, modified, and in one case totally omitted.

The in-depth literature review, case studies and interviews with concerned stakeholders provided the information and laid the foundation for identifying the key causes of delay that may influence the delivery of road and highway projects in Afghanistan.

The results were then used to develop a questionnaire survey as the main research instrument. The questionnaire was aimed at top government and private sector organizations involved in road and highway projects throughout the country. Participants were carefully chosen according to their reputation, expertise and years of experience in different areas pertaining to infrastructure development.

The questionnaire was pilot-tested with professionals from the Ministry of Transport and Afghanistan Builders Association (ABA). Feedback from the pilot study suggested that some of the questions were misleading; some were ambiguous and needed to be rephrased or restructured. After careful consideration of the feedback received through the piloting stage, the questionnaire was adjusted and the final version was devised, including three sections. Section one includes the details of the respondents and their corresponding organizations in order to map out their experience, position, and the type or types of projects they have been involved in. Section two comprises factors that cause delays in road and highway projects during the project preparation, procurement, and implementation phases. The last section focuses on collecting respondents' perceptions, views and opinions of methods for improving road and highway project delivery in the country.

\section{Data Analysis Method}

Out of 100 questionnaires distributed, (50 to the Ministry of Transport and 50 in construction companies) 79 questionnaires were fully and accurately responded to and returned, which indicates an overall response rate of $79 \%$. The respondents were asked to rank the impact of delay causes on road and highway projects using a 5-point Likert scale $(1=$ very low impact; $2=$ low impact; $3=$ average impact; $4=$ high impact; and $5=$ very high impact). The same approach is well-established and widely employed in other construction management research. Furthermore, respondents were asked to add and rate other factors that they believed have an impact on the preparation, procurement and implementation of highway/road projects, but may have not already been included in the questionnaire. The respondents' years of experience are shown in Table 3.

Table 3. Respondents years of experience

\begin{tabular}{ccc}
$\begin{array}{c}\text { Years of } \\
\text { experience }\end{array}$ & $\begin{array}{c}\text { No of } \\
\text { respondents }\end{array}$ & $\begin{array}{c}\text { Percentage } \\
(\%)\end{array}$ \\
\hline 2 to 5 & 13 & $16 \%$ \\
5 to 10 & 14 & $18 \%$ \\
10 to 15 & 35 & $44 \%$ \\
15 and above & 17 & $22 \%$ \\
Total & 79 & $100 \%$ \\
\hline
\end{tabular}

Two statistical techniques are used for analyzing the data collected: RII and Spearman's Rank Correlation.

RII is the most frequently used index for investigating construction delays around the world. According to Long et al. (2008), RII is an appropriate method to rank different factors from various groups of causes. Other researchers, such as, Niazai and Gidado (2012), used a similar approach to investigate construction delays criticality in Afghanistan's construction industry (see also Table 2 for a complete list of previous research in a similar context where the same data analysis methods have been used). The importance index is computed using Eq. (1).

$$
I_{P}=\frac{\sum_{i=1}^{5} a_{i} \cdot n_{i}}{5 N}
$$

Where: $a=$ constant expressing the weight assigned to each response (where $\mathrm{i}$ indicates the number of Likert scales, from 1 [very low impact] to 5 [very high impact]); $\mathrm{n}=$ frequency of the responses for each cause; and $\mathrm{N}=$ total number of responses.

Spearman's Rank Correlation is a relationship measure between different parties or factors, indicating the strength and direction of their relationships. Mainly used to indicate the degree of agreement between different parties, Spearman's Rank Correlation varies between +1 and -1 , with +1 implying complete agreement (or a perfect positive relationship), whereas -1 indicates complete disagreement (corresponding to a perfect negative relationship). The values near zero indicate little to no significant correlation. In this research, this test is used to find out the degree of agreement between parties (see also Table 2 for a complete list of reviewed literature where Spearman's Rank Correlation has been used). This correlation is computed using Eq. (2).

$$
r_{S^{\prime}}=1-\left(\frac{6 \sum d^{2}}{n\left(n^{2}-1\right)}\right)
$$

Where $r_{s^{\prime}}$ : is the Spearman rank correlation coefficient between two parties, $d$ is the difference between ranks assigned to variables for each cause and $n$ is the number of pairs of rank.

\section{Findings and Discussion}

\subsection{Major Causes of Delays}

In this paper, the major causes of delay were categorized into three groups following the main stages of the highway projects, namely: 1) preparation, 2) procurement, and 3) implementation. Furthermore, the paper also looks at clients' and contractors' perspectives on the impact of those 
factors on road and highway projects. Overall, 29 major causes of delay were identified. This was done through an in-depth review of literature, which was then contextualised into Afghanistan's construction industry settings using case analysis of several road and highway projects throughout the country and supplemented by the findings of expert interviews with professionals both in public (central and local governments authorities) and private sectors. These are depicted in Table 4.

Table 4. Major causes of delay in highway projects

\begin{tabular}{|c|c|c|c|}
\hline No & Group & Causes of delay & Reference \\
\hline 1 & \multirow{5}{*}{$\begin{array}{l}\text { Project } \\
\text { preparation }\end{array}$} & $\begin{array}{l}\text { Inaccurate design and bills of quantities } \\
\text { (Inaccuracy in design throughout the entire process down to } \\
\text { inaccurate bills of quantities for cost estimation) }\end{array}$ & $\begin{array}{l}\text { CoST First Assurance } \\
\text { Report (2018) }\end{array}$ \\
\hline 2 & & Changes in project scopes and/or design & Kim et al. 2016 \\
\hline 3 & & $\begin{array}{l}\text { Outdated survey and project's initial design drawing } \\
\text { documents }\end{array}$ & From the interview \\
\hline 4 & & Incompetence in the survey or design teams & From the interview \\
\hline 5 & & Delay in awarding the contract after biding & From the interview \\
\hline 6 & \multirow{8}{*}{ Procurement } & Award project to the lowest bid price & Mahamid et al. (2012) \\
\hline 7 & & Corruption in the procurement process & Gidado and Niazi (2012) \\
\hline 8 & & $\begin{array}{l}\text { Award project to Incompetence contractor (due to nepotism, } \\
\text { cronyism, or corruption) }\end{array}$ & From the interview \\
\hline 9 & & Disregarding procurement law and regulation & From the interview \\
\hline 10 & & Political interference during the award of contract & From the interview \\
\hline 11 & & $\begin{array}{l}\text { Non-consideration of security risks in the procurement } \\
\text { process }\end{array}$ & From the interview \\
\hline 12 & & Non-compliance with FIDIC contract format & From the interview \\
\hline 13 & & $\begin{array}{l}\text { lack of reasonable and fair allocation of risks in public } \\
\text { contracts }\end{array}$ & From the interview \\
\hline 14 & \multirow{16}{*}{ Implementation } & Progress payment delays by owner & Mahamid et al. (2012) \\
\hline 15 & & $\begin{array}{l}\text { Shortage of equipment and material or financial status of } \\
\text { contractors (the shortage might be due to lack of access to } \\
\text { equipment and materials or due to financial restriction } \\
\text { experienced by the contractor) }\end{array}$ & Mahamid et al. (2012) \\
\hline 16 & & Security (war, theft, kidnapping, etc.) & Gidado and Niazi (2012) \\
\hline 17 & & $\begin{array}{l}\text { Inflation and foreign currency exchange rate fluctuation and } \\
\text { their impact on construction materials, equipment and } \\
\text { services and labor costs (pay rates) }\end{array}$ & $\begin{array}{l}\text { CoST first assurance report } \\
(2018)\end{array}$ \\
\hline 18 & & $\begin{array}{l}\text { Local communities demand for changes in project scope or } \\
\text { design }\end{array}$ & $\begin{array}{l}\text { CoST first assurance report } \\
(2018)\end{array}$ \\
\hline 19 & & Land acquisition & $\begin{array}{l}\text { CoST 2nd assurance report } \\
\text { (2019) }\end{array}$ \\
\hline 20 & & Climate and Weather condition & $\begin{array}{l}\text { CoST 2nd assurance report } \\
\text { (2019) }\end{array}$ \\
\hline 21 & & Financial difficulties to the owner & Kim et al. (2016) \\
\hline 22 & & Insufficient contractors' experience & Kim et al. (2016) \\
\hline 23 & & $\begin{array}{l}\text { Lack of coordination and cooperation between client and } \\
\text { contractor/ stakeholders }\end{array}$ & Alaghbari et al. (2007) \\
\hline 24 & & $\begin{array}{l}\text { Lack of client capacity or expertise to monitor the project } \\
\text { progress) }\end{array}$ & From the interview \\
\hline 25 & & Poor qualification of the contractor's technical staff & Gidado and Niazi (2012) \\
\hline 26 & & $\begin{array}{l}\text { Poor site management and weak supervision by the } \\
\text { contractor }\end{array}$ & Gidado and Niazi (2012) \\
\hline 27 & & $\begin{array}{l}\text { Corruption during the implementation and supervision of the } \\
\text { project }\end{array}$ & From the interview \\
\hline 28 & & Problem creation by the supervision team due to favouritism & From the interview \\
\hline 29 & & $\begin{array}{l}\text { imbalanced and unrealistic working schedule (non- } \\
\text { consideration of holidays, seasonal weather conditions, etc.) }\end{array}$ & From the interview \\
\hline
\end{tabular}


The RII was then used to rank major causes of delay in road and highway projects. Both parties, clients and contractors, contributed to this ranking. Building upon Table 4 and triangulated with the findings of the primary research in this study, Table 5 presents the ten key factors ranked by clients and contractors. From the clients' perspective, "Shortage of equipment and material or financial status of contractors" followed by "Insufficient contractors' experience" is the most severe cause of delay by the contractors. Contractors reported that "nonconsideration of security risks in the procurement process" followed by "Security" (war, theft, kidnapping, etc.) are the significant causes of delay in highway projects.
Using an overall RII, the top 10 significant factors causing a delay in road and highway projects in Afghanistan are presented in Table 6. The findings clearly indicate that "Security" (war, theft, kidnapping, etc.) with an overall importance index of 0.871 is the most important factor contributing to delays in highway projects in Afghanistan. The survey results concur with the findings by Niazai and Gidado (2012), where they outlined security as the major cause of delays in construction projects in Afghanistan. This is true as the security situation in Afghanistan has not improved since 2012 at all, if not further deteriorated.

Table 5. Client and contractor's perspective on the importance of delay causes

\begin{tabular}{|c|c|c|}
\hline Rank & Client & Construction Companies \\
\hline 1 & $\begin{array}{l}\text { Shortage of equipment and material or financial status } \\
\text { of contractors (the shortage might be due to lack of } \\
\text { access to equipment and materials or due to financial } \\
\text { restriction experienced by the contractor) }\end{array}$ & $\begin{array}{l}\text { Non-consideration of security risks in the } \\
\text { procurement process }\end{array}$ \\
\hline 2 & Insufficient contractors' experience & Security (war, theft, kidnapping, etc.) \\
\hline 3 & Security (war, theft, kidnapping, etc.) & Corruption in the procurement process \\
\hline 4 & Poor qualification of the contractor's technical staff & $\begin{array}{l}\text { Inaccurate design and bills of quantities (Inaccuracy } \\
\text { in design throughout the entire process down to } \\
\text { inaccurate bills of quantities for cost estimation) }\end{array}$ \\
\hline 5 & Land acquisition & Progress payment delays by owner \\
\hline 6 & $\begin{array}{l}\text { Award project to Incompetence contractor (due to } \\
\text { nepotism, cronyism, or corruption) }\end{array}$ & Award project to the lowest bid price \\
\hline 7 & $\begin{array}{l}\text { Poor site management and weak supervision by the } \\
\text { contractor }\end{array}$ & Land acquisition \\
\hline 8 & Corruption in the procurement process & Delay in awarding the contract after biding \\
\hline 9 & Progress payment delays by owner & $\begin{array}{l}\text { Shortage of equipment and material or financial } \\
\text { status of contractors (the shortage might be due to } \\
\text { lack of access to equipment and materials or due to } \\
\text { financial restriction experienced by the contractor) }\end{array}$ \\
\hline 10 & $\begin{array}{l}\text { Inaccurate design and bills of quantities (Inaccuracy in } \\
\text { design throughout the entire process down to } \\
\text { inaccurate bills of quantities for cost estimation) }\end{array}$ & Financial difficulties to the owner \\
\hline
\end{tabular}

Table 6. Overall RII and ranking of top 10 significant causes of delay in highway projects

\begin{tabular}{|c|c|c|c|c|c|c|}
\hline \multirow{2}{*}{ Causes of delay } & \multicolumn{2}{|c|}{ Client } & \multicolumn{2}{|c|}{ Contractor } & \multicolumn{2}{|c|}{ Overall } \\
\hline & Index & Rank & Index & Rank & Index & Rank \\
\hline Security (war, theft, kidnapping, etc.) & 0.850 & 3 & 0.892 & 2 & 0.871 & 1 \\
\hline $\begin{array}{l}\text { Shortage of equipment and material or financial status of } \\
\text { contractors (the shortage might be due to lack of access to } \\
\text { equipment and materials or due to financial restriction } \\
\text { experienced by the contractor) }\end{array}$ & 0.867 & 1 & 0.815 & 9 & 0.841 & 2 \\
\hline Land acquisition & 0.825 & 5 & 0.846 & 7 & 0.836 & 3 \\
\hline Corruption in procurement process & 0.789 & 8 & 0.877 & 3 & 0.833 & 4 \\
\hline Progress payment delays by owner & 0.785 & 9 & 0.874 & 5 & 0.829 & 5 \\
\hline Non-consideration of security risks in the procurement process & 0.760 & 13 & 0.895 & 1 & 0.827 & 6 \\
\hline $\begin{array}{l}\text { Inaccurate design and bills of quantities (Inaccuracy in design } \\
\text { throughout the entire process down to inaccurate bills of } \\
\text { quantities for cost estimation) }\end{array}$ & 0.774 & 10 & 0.876 & 4 & 0.825 & 7 \\
\hline Insufficient contractors' experience & 0.855 & 2 & 0.790 & 19 & 0.822 & 8 \\
\hline Poor qualification of the contractor's technical staff & 0.847 & 4 & 0.795 & 16 & 0.821 & 9 \\
\hline Award project to lowest bid price & 0.759 & 14 & 0.856 & 6 & 0.808 & 10 \\
\hline
\end{tabular}


"Shortage of equipment and material or financial status of the contractor" with an overall RII of 0.841 is reported as the second major cause of delay in highway projects. The shortage might be due to a lack of access to equipment and materials or due to financial restrictions experienced by the contractor. A report by Thailand's Department of Highways also identified a "lack of equipment efficiency or financial status of contractors" as the second most important factor causing a delay in highway projects in Thailand.

"Land acquisition and resettlement" is defined as the loss of one's home or land in connection with project implementation (Patrick, 2007). With an overall RII of 0.836 , it has been identified as the third important factor causing delays in highway projects in Afghanistan. The process of land acquisition, compensation, and resettlement for those who will be required to leave their homes and land for the greater good of the public (so that the public works can be carried out) are cumbersome and painful in Afghanistan. As per CoST Afghanistan's 2nd Assurance Report (2019), "Land acquisition" is considered as one of the most significant factors causing delays in most construction projects. For instance, land acquisition, among other factors, delayed Karta-e- Ariana Road in the heart of the capital by $298 \%$ and Kabul-Logar road by $44.4 \%$, while both projects were reported ongoing and further delays could be expected (CoST 2019).

"Corruption in the procurement process" with an importance index of 0.833 is ranked 4th, significantly contributing to delay in highway projects. The construction industry is described as an inherently untransparent industry, and corrupt practices transpire at all levels and phases of project development (TI 2013). Corruption was also identified previously as the second major factor contributing to delay in construction projects (Niazai and Gidado 2012). Corruption in the construction industry could happen in different forms such as fraud, fronting, bribery, kickbacks, conflicts of interest, collusion and bid rigging, nepotism, cronyism and other unfair or unethical conducts (Brown and Loosemore 2015). Corruption could lead to numerous malpractices during the procurement of road and highway projects. Award of contract to incompetent contractors, who are not technically and financially eligible, could be one of the common practices in Afghanistan as suggested in numerous international reports during the reconstruction period in the country.

"Progress payment delay by owner" is ranked 5th with an overall importance index of 0.829 . Delay in progress payment by the client could have several consequences on road and highway projects, such as difficulties in financing projects by the contractor(s) and shortage of materials.
Construction companies believe that the main reasons for the delay in payments are the slow decision-making process by clients due to lack of using technology and corrupt practices mainly around or associated with the project supervision and control teams.

"Non-consideration of security risks in the procurement process" is ranked 6th with an RII of 0.827 . This factor is ranked 'first' by contractors and could be justified that given the security issues in Afghanistan, mitigating security risks could play a significant role in the successful implementation of road and highway projects. Both clients and contractors do not pay enough attention to this risk during the procurement process and this factor seems to usually be compromised when aiming for the lowest price bids during competition or tendering processes.

Inaccurate design and bills of quantities (BoQs) with an important index of 0.825 is ranked $7^{\text {th }}$. Although the design and BoQs could be treated as separate factors, given their strong interrelationship with each other it is quite natural for the two factors to be seen so closely intertwined and referred to in conjunction with one another by the participants not only during the course of this study but also in some previous studies as indicated through the review of existing literature. This factor is defined as Inaccuracy in design throughout the entire process down to inaccurate bills of quantities for cost estimation. Inaccuracy in design was also found as one of the most important factors causing a delay in construction projects in CoST 2018 report. BoQs is usually estimated based on the design and contractors believe that due to errors in design, the amount of quantities does not correspond to the real quantities to be achieved and thus it leads to changes in the design and alteration in the project cost. Considering the bureaucratic approaches for approval of changes during the construction of roads and highways, the process is lengthy and could take months, if not years to approve.

Insufficient contractor experience, poor qualification of the contractor's technical staff, and award project to lowest bid with an importance index of $0.822,0.821,0.808$ is ranked $8^{\text {th }}, 9^{\text {th }}$ and $10^{\text {th }}$ respectively. Overall RII and ranking of the top 10 significant causes of delay in highway projects are presented in Table 6.

The causes of delay in road projects were also ranked under each source group of delays. As seen in Table 7, the most important factor that contributes to delay under the project preparation group is "inaccurate design and bills of quantities" followed by "outdated survey and project's initial design drawing documents."

Table 7. Ranking of causes under project preparation group

\begin{tabular}{|c|c|c|c|c|c|}
\hline $\begin{array}{c}\text { Source } \\
\text { group }\end{array}$ & Causes of delay & $\begin{array}{l}\text { Client } \\
\text { index }\end{array}$ & $\begin{array}{c}\text { Contractor } \\
\text { index }\end{array}$ & $\begin{array}{c}\text { Overall } \\
\text { Index }\end{array}$ & Rank \\
\hline \multirow{5}{*}{ 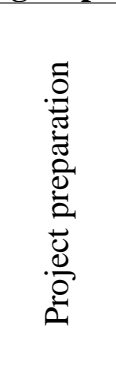 } & $\begin{array}{l}\text { Inaccurate design and bills of quantities (Inaccuracy in } \\
\text { design throughout the entire process down to inaccurate } \\
\text { bills of quantities for cost estimation) }\end{array}$ & 0.774 & 0.876 & 0.825 & 1 \\
\hline & $\begin{array}{l}\text { Outdated survey and project's initial design drawing } \\
\text { documents }\end{array}$ & 0.733 & 0.795 & 0.764 & 2 \\
\hline & Delay in awarding the contract after biding & 0.705 & 0.817 & 0.761 & 3 \\
\hline & Changes in project scopes and/or design & 0.710 & 0.772 & 0.741 & 4 \\
\hline & incompetence in the survey or design teams & 0.676 & 0.719 & 0.697 & 5 \\
\hline
\end{tabular}


"Corruption in the procurement process," followed by "non-consideration of security risk during the procurement of highway projects" and "award project to lowest bid price" are identified as the most key factors causing delay under the procurement group (Table 8).

Finally, as indicated in Table 9, "Security" (war, theft, kidnapping, etc.) and "shortage of equipment and materials or financial status of contractors" are the two most important factors, followed by "land acquisition" causing a delay in highway projects under the implementation group.

\subsection{Ranking of Source Groups of Delays}

The causes of delay are categorized into three groups. The ranking of these groups is associated with the degree of severity as indicated by clients and contractors (as shown in Table 10). Clients ranked implementation related factors as the most important source of delay, while contractors ranked implementation related factors as the 3rd source of delay and procurement as the 1 st. The overall combination of the result shows that 'implementation' is the most important source of delay, followed by 'procurement' and 'project preparation' as the second and third significant source group of delays.

Table 8. Ranking of causes under procurement group

\begin{tabular}{|c|c|c|c|c|c|}
\hline $\begin{array}{l}\text { Source } \\
\text { group }\end{array}$ & Causes of delay & $\begin{array}{l}\text { Client } \\
\text { index }\end{array}$ & $\begin{array}{l}\text { Contractor } \\
\text { index }\end{array}$ & $\begin{array}{c}\text { Overall } \\
\text { index }\end{array}$ & Rank \\
\hline \multirow{8}{*}{ Procurement } & Corruption in procurement process & 0.789 & 0.877 & 0.833 & 1 \\
\hline & $\begin{array}{l}\text { Non-consideration of security risks in the procurement } \\
\text { process }\end{array}$ & 0.760 & 0.895 & 0.827 & 2 \\
\hline & Award project to lowest bid price & 0.759 & 0.856 & 0.808 & 3 \\
\hline & $\begin{array}{l}\text { Award project to Incompetence contractor (due to } \\
\text { nepotism, cronyism, or corruption) }\end{array}$ & 0.795 & 0.805 & 0.800 & 4 \\
\hline & Political interference during the award of contract & 0.763 & 0.774 & 0.768 & 5 \\
\hline & Disregarding procurement law and regulation & 0.694 & 0.768 & 0.731 & 6 \\
\hline & $\begin{array}{l}\text { lack of reasonable and fair allocation of risks in public } \\
\text { contracts }\end{array}$ & 0.611 & 0.806 & 0.708 & 7 \\
\hline & Non-compliance with FIDIC contract format & 0.595 & 0.722 & 0.658 & 8 \\
\hline
\end{tabular}

Table 9. Ranking of causes under implementation group

\begin{tabular}{|c|c|c|c|c|c|}
\hline Source group & Causes of delay & $\begin{array}{l}\text { Client } \\
\text { index }\end{array}$ & $\begin{array}{l}\text { Contractor } \\
\text { index }\end{array}$ & $\begin{array}{l}\text { Overall } \\
\text { index }\end{array}$ & Rank \\
\hline \multirow{16}{*}{ Implementation } & Security (war, theft, kidnapping, etc.) & 0.850 & 0.892 & 0.871 & 1 \\
\hline & $\begin{array}{l}\text { Shortage of equipment and material or financial status } \\
\text { of contractors (the shortage might be due to lack of } \\
\text { access to equipment and materials or due to financial } \\
\text { restriction experienced by the contractor) }\end{array}$ & 0.867 & 0.815 & 0.841 & 2 \\
\hline & Land acquisition & 0.825 & 0.846 & 0.836 & 3 \\
\hline & Progress payment delays by owner & 0.785 & 0.874 & 0.829 & 4 \\
\hline & Insufficient contractors' experience & 0.855 & 0.790 & 0.822 & 5 \\
\hline & Poor qualification of the contractor's technical staff & 0.847 & 0.795 & 0.821 & 6 \\
\hline & $\begin{array}{l}\text { Lack of coordination and cooperation between client } \\
\text { and contractor/ stakeholders }\end{array}$ & 0.770 & 0.805 & 0.788 & 7 \\
\hline & Financial difficulties to owner & 0.730 & 0.811 & 0.770 & 8 \\
\hline & $\begin{array}{l}\text { Problem creation by the supervision team due to } \\
\text { favouritism }\end{array}$ & 0.732 & 0.805 & 0.768 & 9 \\
\hline & $\begin{array}{l}\text { Corruption during the implementation and } \\
\text { supervision of the project }\end{array}$ & 0.735 & 0.789 & 0.762 & 10 \\
\hline & $\begin{array}{l}\text { Poor site management and weak supervision by } \\
\text { contractor }\end{array}$ & 0.790 & 0.700 & 0.745 & 11 \\
\hline & $\begin{array}{l}\text { imbalanced and unrealistic working schedule (non- } \\
\text { consideration of holidays, seasonal weather } \\
\text { conditions, etc.) }\end{array}$ & 0.646 & 0.794 & 0.720 & 12 \\
\hline & $\begin{array}{l}\text { Lack of client capacity or expertise to monitor the } \\
\text { project progress }\end{array}$ & 0.735 & 0.697 & 0.716 & 13 \\
\hline & $\begin{array}{l}\text { Inflation and foreign currency exchange rate } \\
\text { fluctuation and their impact on construction materials, } \\
\text { equipment and services and labor costs (pay rates) }\end{array}$ & 0.595 & 0.795 & 0.695 & 14 \\
\hline & $\begin{array}{l}\text { Local communities demand for changes in project } \\
\text { scope or design }\end{array}$ & 0.595 & 0.753 & 0.674 & 15 \\
\hline & Climate and weather condition & 0.555 & 0.697 & 0.626 & 16 \\
\hline
\end{tabular}


Table 10. Ranking of sources (groups) of delays

\begin{tabular}{lcccccc}
\hline \multirow{2}{*}{ Source Groups of delays } & \multicolumn{2}{c}{ Client } & \multicolumn{2}{c}{ Contractor } & \multicolumn{2}{c}{ Overall RII } \\
\cline { 2 - 7 } & Index & Rank & Index & Rank & Index & Rank \\
\hline Implementation & 0.744 & 1 & 0.789 & 3 & 0.767 & 1 \\
Procurement & 0.721 & 2 & 0.813 & 1 & 0.767 & 2 \\
Project preparation & 0.720 & 3 & 0.791 & 2 & 0.755 & 3 \\
\hline
\end{tabular}

\subsection{Importance Rank Correlation}

The Spearman's rank correlation coefficient is applied to measure the degree of agreement (or otherwise) associated with the importance ranking of the two stakeholder groups - clients and contractors - for each factor of delay. The calculation of Spearman's coefficient indicates that the agreement between clients and contractors is $46 \%$. The Spearman's coefficient is also used to rank the degree of agreement among source groups of delay. It was found that the agreement between clients and contractors on the severity of sources of delay is $75 \%$.

\section{Conclusion and Recommendations}

Afghanistan is a landlocked country. To improve regional connectivity and provide access to markets, construction of roads and highways on time is essential hence one of the government's top priorities. For a country suffering from endemic levels of unemployment, the ability to connect people, goods and services provide a critical opportunity for social and economic development as it helps facilitate rebuilding what has been ruined as a result of nearly three decades of war. However, both clients and contractors have roles in failures associated with on-time and on-budget delivery of highway and road projects. Afghanistan's ring road and many other roads across the country could be examples of delays in road projects. Delays have caused a multitude of negative impacts on both clients and contractors, preventing the government from delivering its economic development promises and aspirations.

The first measure in reducing delays in road and highway projects is to understand the root causes of delay; hence the aim of this research was to identify the main causes of delay that affect road and highway projects in Afghanistan. A literature review and expert interviews were conducted to identify the causes of delay, first as a scenesetting in an international comparative context and then more specifically in Afghanistan. As a result, 29 causes of delay were identified. The delay causes were then categorized into three main groups: project preparation, procurement and implementation. For further quantitative evaluation, a questionnaire survey was designed and distributed to 100 participants in the Ministry of Transport and construction companies. The aim of the questionnaire was to identify the most important causes of project delay in highway projects. A response rate of $79 \%$ was obtained. The importance index was used to rank the effect of each cause of delay.

From the overall result, it was found that "security" including issues associated with or caused by war, theft, kidnapping, etc., were considered the most important causes of delay in road projects in Afghanistan. This was followed by 2) shortage of equipment and material or financial status of contractors, 3) land acquisition, 4) corruption in the procurement process, and 5) progress payment delays by owner/client, as the top five important factors causing a delay in road projects in Afghanistan. Using Spearman's correlation index, the degree of agreement between clients and contractors was identified as $46 \%$.

In terms of group ranking, contractors indicated that 'procurement' was the most significant source of delays, while the client specified 'implementation' as the most important source of delays. The combined result of group causes showed that delays are caused through "Implementation" followed then by "procurement" and finally "project preparation." The Spearman's correlation rank indicated that the degree of agreement on delay sources between clients and contractors is $75 \%$.

To minimize and control delays in road and highway projects, the government of Afghanistan and construction companies would need to consider the following points:

1. Security was found as the most important factor causing delays in highway projects. Government and contractors need to identify innovative ways to mitigate this risk during the procurement of roads and highways. In those projects that are affected by security issues, it would be good to identify the magnitude of this risk and consider it in the procurement process. Contractors could take measures such as hiring more security companies/staff or negotiation with insurgents involving the local elders and tribal heads. Most development projects are welcomed by the local people and the government and contractors need to design and run public awareness programmes and involve people actively in the projects and seek their support during the implementation. The government of Afghanistan has signed up to initiatives such as CoST and OCP and their standards and good practices could be considered as a tool for public engagement in the procurement of road and highway projects.

2. "Shortage of equipment and material as a result of the financial status of contractors" was identified as the second most important factor causing a delay in highway projects. Attention during the evaluation of bids and selection of contractors that are financially eligible and technically competent could play a significant role in mitigating this risk. Contractors also believe that delay in progress payments by clients leads to a shortage of material and procurement or plants and equipment, and that even sometimes the delay in payments has made contractors go bankrupt. Attention to the acceleration of payments to contractors through using technology and removing bureaucratic and unnecessary processes could significantly alleviate this risk.

3. Contractors need to increase the capacity of their technical staff to enable themselves to effectively manage the planning and scheduling of the work and to improve site management and supervision to achieve quality completion of work within a specified time and budget. It is also 
important for contractors to manage the financial resources and to plan cash flow by utilizing progress payments.

4. Government needs to solve "land acquisition and settlement" issues during the planning and prior to the design stages of the projects. This will help avoid any delays associated with or caused by land acquisition during the implantation of projects.

5. Corruption perception during the procurement of road and highway projects reduces trust among stakeholders and leads to unfair business opportunities in the country. The government needs to build trust through adopting relevant up-to-date technologies in the procurement process, such as launching e-tendering. Enabling technology to help evaluate bids and to make decisions about the selection of contractors will help minimize personal interference and reduce favoritism during the procurement process and could potentially reduce corruption and monetary risks.

6. Ministry of Transport needs to improve the capacity of their survey and design teams to produce more up-todate, reliable and accurate design documents, especially, more attention should be paid to the bills of quantities. Design freeze and eliminating or minimizing changes and amendments during the construction phase and speeding up the decision-making process for approving the absolutely necessary changes could be encouraged. This will set exemplars of good practice and can be used as a means of rewarding contractors which will have some direct positive impacts on reducing delays in highway projects.

\section{Research Limitations and Implications}

Delay in construction projects, especially in road and highway projects, is a worldwide phenomenon, and a cause for a multitude of negative impacts on key project stakeholders - clients, contractors and the general public. Despite this fact and while here is a plethora of research on delay in building construction projects, causes of delays in road and highway projects are less researched. On the other hand, due to several reasons, the lack of sufficient systematic studies on Afghanistan's construction industry is not an unknown fact. This research contributes, on the one hand, to the body of knowledge on delays in a very specific - and less researched - sector of the construction industry, i.e., roads and highways, and on the other, to the body of knowledge specifically designed and conducted with the contextual, local and regional characteristics of Afghanistan's construction industry.

Practical implications: The findings of this research will help clients and contractors to mitigate or prevent delays in road and highway projects in Afghanistan. To help overcome delays in road and highway projects more effectively, recommendations have been made for fundamental reforms in procurement systems for major projects in Afghanistan.

Social implications: Afghanistan is a landlocked country. To improve regional and international trade and to provide access to markets across the country, construction of roads and highways on time and within budget is one of the Afghanistan Government's top priorities. For a country suffering from endemic levels of unemployment, the ability to connect people, goods and services provide a critical opportunity for social and economic development as it rebuilds after nearly three decades of war. The findings of this study will be provided in the form of an executive summary and presented to local and central government authorities to inform decisions at local and policy at national levels, and will have direct and indirect impacts on the day-to-day lives of tens of thousands of Afghanistan's population who will benefit from better road and highway networks throughout the country.

Originality and value: So far, many studies have been carried out on the causes of delays in construction projects. However, the studies on causes of delays in road and highway construction projects are few and far between and there is none in this specific area in Afghanistan. The specificity of the causes of delays in road and highway projects makes this study of unique and outstanding value with some applicability to similar or identical construction economies throughout the world. The practical and social implications of this study for the country of study and the region also give this study an exclusive value to those who will be at the receiving end of the benefits of this study.

\section{References}

Abd El-Razek, M. E., Bassioni, H. A., and Mobarak, A. M. (2008). Causes of delays in building construction projects in Egypt. Journal of construction engineering and management, 134 (11), 831-841.

Ahmed. S.M., Azhar. S., Castillo. M., and Kappagantula. P. (2001) Construction delays in Florida: an empirical study, State of Florida, Department of Community Affairs. Final report. Department of Community Affairs, Florida, US.

Alaghbari, W. E., Kadir, M. R. A., and Salim, A. (2007). (2007) The significant factors causing delay of building construction projects in Malaysia. Engineering, Construction and Architectural Management, 14 (2). pp. 192-206. ISSN 0969-9988; ESSN: 1365-232X

Baligh, M. (2017). Afghanistan Transport Sector Master Plan Update (2017-2036). Asian Development Bank Publisher. Manila. Philippines, 4. Retrieved from https://www.adb.org/sites/default/files/institutionaldocument/327561/afg-transport-plan-2017-2036.pdf, on 21 July 2020.

Assaf. S.A. and Al-Hejji. S. (2006). Causes of delay in large construction projects, Int. J. Project Manage, 24 (4) (2006) 349-357.

Aziz, R. F. and Abdel-Hakam, A. A. (2016). Exploring delay causes of road construction projects in Egypt, Alexandria Engineering Journal, 55, 1515-1539

Brown, J. and Loosemore, M. (2015). Behavioral factors influencing corrupt actions in the Australian construction industry. Eng. Constr. Archit. Manage, 22(4), 372-389.

The CoST Afghanistan (2018). First Assurance Report on Public Infrastructure Projects, CoST: The Infrastructure Transparency Initiative-Afghanistan. Retrieved from http://cost.af/english/wpcontent/uploads/2017/10/CoST-Afghanistan-1stAssurance-Report.pdf, on the 21 July 2020.

The CoST Afghanistan (2019). Second Assurance Report on Public Infrastructure Projects, CoST: The Infrastructure Transparency Initiative-Afghanistan, Retrieved from http://cost.af/english/wpcontent/uploads/2019/11/CoST-Afghanistan-2ndAssurance-Report-English-2019.pdf, on 21 July 2020. CSO (2017). Afghanistan Living Conditions Survey 2016-17, Central Statistics Organization. Retrieved from: https://www.nsia.gov.af:8080/wp- 
content/uploads/2019/04/ALCS-2016-17-Analysisreport-.pdf, on the 21 July 2020.

Dissanayaka, S. M. and Kumaraswamy M. M. (1999). Comparing contributors to time and cost performance in building projects. Building and Environment, 34(1), 31-42.

Frimponga, Y, Oluwoyeb, J., and Crawfordc, L (2003). Causes of delay and cost overruns in construction of groundwater projects in a developing countries, Ghana as a case study. International Journal of Project Management; 21, 321-326

Gidado, K. and Niazai, G. (2012). Causes of project delay in the construction industry in Afghanistan: EPPM 2012, University of Brighton, UK.

Mahamid, I., Bruland, A., and Dmaidi, N. (2012), Cause of Delay in Road Construction Projects, Journal of Management in Engineering, Vol.28, 300 - 310

Jung. M, Park. M, Lee. H, Kim. H (2016). Weather-delay simulation model based on vertical weather profile for high-rise building construction, Journal of Construction Engineering \& Management. 142(6).

Knoema (2020). Afghanistan Road Density, World Data Atlas/Afghanistan/Transportation. Retrieved from https://knoema.com/atlas/Afghanistan/Road-density on the 21 July 2020.

Long, L.H., Lee, Y.D. and Lee, J. Y. (2008) Delay and Cost Overruns in Vietnam Large Construction Projects: A Comparison with Other Selected Countries. Journal of Civil Engineering, 12(6), 367-377.

Menesi. W (2007) Construction delay analysis under multiple baseline updates, A Thesis Presented to the University of Waterloo in Fulfillment, the Thesis Requirement for the Degree of Master of Applied Science, Waterloo, Ontario, Canada

Ministry of Transport, 2019-2023 Strategy. Retrieved from https://mot.gov.af/sites/default/files/201909/Strategy\%20Dari_0.pdf, on the 21 July 2020.

Odeyinka H.A. and Yusif A. (1997), The causes and effects of construction delays on completion cost of housing projects in Nigeria. Financial Manage Property Construction, 2(3) 31-44.

Orangi. A., Palaneeswaran. E., and Wilson. J (2011) Exploring Delays in Victoria-Based Astralian Pipeline Projects, Procedia Engineering, 14 (2011) 874-881

Palaneeswaran, E. and Kumaraswamy, M.M. (2008). An integrated decision support system for dealing with time extension claims in construction projects. Automation in Construction, 17(4) 425-438.

Report on Department of Highways, Highways Construction Performance Evaluation in Fiscal Year 2014 and 2015, Department of Highways, Ministry of Transports, Bangkok, Thailand

Sambasivan, M. and Soon, Y (2007). Causes and effects of delays in Malaysian construction industry. International Journal of Project Management, 25, 517-526.

SIGAR (2016), Afghanistan's Road Infrastructure: Sustainment Challenges and Lack of Repairs Put U.S. Investment at Risk, Special Inspector General for Afghanistan Reconstruction. Retrived from https://www.sigar.mil/pdf/audits/SIGAR-17-11AR.pdf on the the 21 July 2020.

Kim, S. Y., Tuan, K. N., \& Luu, V. T. (2016). Delay Factor Analysis for Hospital Projects in Vietnam, KSCE Journal of Civil Engineering, 20, 519 - 529

Transparency International. (2013). Preventing corruption on construction projects. Retrieved from hhttp://archive.transparency.org/tools/contracting/cons truction projects on the 21 July 2020.

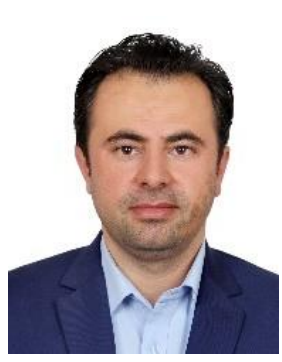

Sebghatullah Karimi holds M.Sc in Construction Project Management (2012) and B. Sc in Construction Management (2011) from the United Kingdom, and B.Sc in Civil Engineering (2006) from Kabul Polytechnic University (KPU). He is a lecturer in KPU and the country manager for CoST: The Infrastructure Transparency Initiative-Afghanistan for the past 13 and 5 years, respectively. He has more than 14 years of experience in the construction industry and academia, and has worked for national and international organizations. His research interest covers project management and procurement of construction projects. Mr. Karimi has presented and published several papers in the national and international journals and conferences in the UK, Australia and Afghanistan, and also published several chapter books, reports and manuals. Mr. Karimi was part of the research team for Scoping Study of CoST Afghanistan which laid the foundation of establishing this initiative and beginning the infrastructure data disclosure culture in the public sector. He also supervised the research team responsible for the development of the First Assurance Report, and led the research for Second and Third Assurance Reports on infrastructure projects in Afghanistan.

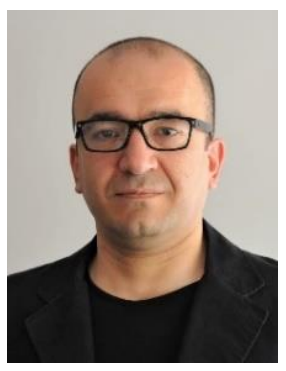

Dr. Poorang Piroozfar is a reader in architectural technology and digital construction, the academic program leads for BSc (Hons) architectural technology, and MSc Digital Construction, and director of Digital Construction $\mathrm{Lab}$ in School of Architecture, Technology and Engineering, University of Brighton, UK. Poorang has designed, led and delivered multidisciplinary and cross-disciplinary research projects on intersections between theory, knowledge, technology, people and environment. Poorang's research as an architect, urban designer, and architectural technologist, spans over a variety of areas with a Multi-, Cross-, Inter- and Trans-disciplinary nature. He has led seven Ph.D. students to successful completion, has delivered nationally and internationally funded research and contributed to UK policy documents on offsite manufacturing/construction. He has won over eight international awards for his research and journal/conference publications. Dr. Piroozfar has been a member of the leadership team for Research Excellence Framework submission and has led dissertation and research taught modules at undergraduate and postgraduate levels in the School of Environment and Technology, University of Brighton. 